\title{
Author Correction: Directional Exosome Proteomes Reflect Polarity-Specific Functions in Retinal Pigmented Epithelium Monolayers
}

\author{
Mikael Klingeborn ${ }^{1}$, W. Michael Dismuke ${ }^{1}$, Nikolai P. Skiba ${ }^{1}$, Una Kelly $^{1}$, W. Daniel Stamer ${ }^{1,2}$ \& \\ Catherine Bowes Rickman ${ }^{1,3}$
}

Correction to: Scientific Reports https://doi.org/10.1038/s41598-017-05102-9, published online 07 July 2017

This Article contains typographical errors in the Acknowledgements section.

“This study was supported by a BrightFocus Foundation grant M2015221 (MK), NIH grants EY023468 (WMD), EY0123456 (CBR), EY023287 (WDS), EY022359 (WDS), EY019696 (WDS), a Glaucoma Research Foundation Shaffer Grant (WMD, WDS), and a grant from the Foundation Fighting Blindness (CBR). A Core Grant for Vision Research (P30; EY5722) from NEI (to Duke University), supported much of the work, including the mass spectrometric analyses carried out by NPS."

should read:

“This study was supported by a BrightFocus Foundation grant M2015221 (MK), NIH grants EY023468 (WMD), EY026161 (CBR), EY023287 (WDS), EY022359 (WDS), EY019696 (WDS), a Glaucoma Research Foundation Shaffer Grant (WMD, WDS), and a grant from the Foundation Fighting Blindness (CBR). A Core Grant for Vision Research (P30; EY5722) from NEI (to Duke University), supported much of the work, including the mass spectrometric analyses carried out by NPS."

(i) Open Access This article is licensed under a Creative Commons Attribution 4.0 International License, which permits use, sharing, adaptation, distribution and reproduction in any medium or format, as long as you give appropriate credit to the original author(s) and the source, provide a link to the Creative Commons license, and indicate if changes were made. The images or other third party material in this article are included in the article's Creative Commons license, unless indicated otherwise in a credit line to the material. If material is not included in the article's Creative Commons license and your intended use is not permitted by statutory regulation or exceeds the permitted use, you will need to obtain permission directly from the copyright holder. To view a copy of this license, visit http://creativecommons.org/licenses/by/4.0/.

(C) The Author(s) 2018

\footnotetext{
${ }^{1}$ Department of Ophthalmology, Duke Eye Center, Duke University, Durham, NC, 27710, USA. ${ }^{2}$ Department of Biomedical Engineering, Duke University, Durham, NC, 27710, USA. ${ }^{3}$ Department of Cell Biology, Duke University, Durham, NC, 27710, USA. Correspondence and requests for materials should be addressed to M.K. (email: mikael. klingeborn@duke.edu) or C.B.R. (email: bowes007@duke.edu)
} 